\title{
GAMBARAN GAYA HIDUP PENDERITA HIPERTENSI DI PUSKESMAS BUA TALLULOLO TORAJA UTARA PADA MASA PANDEMI
}

\author{
Mada Pasalli Saludung ${ }^{1}$, Evelin Malinti ${ }^{2}$ \\ 1, 2 Universitas Advent Indonesia \\ E-mail: mada05pasallisaludung@gmail.com
}

\begin{abstract}
Upaya pencegahan covid-19 berhubungan dengan perubahan gaya hidup masyarakat baik yang sehat maupun yang menderita komorbid. Hipertensi diketahui menjadi salah satu komorbid yang rentan dan berhubungan dengan keparahan gejala yang dialami oleh penderita covid-19. Penelitian ini bertujuan untuk menggambarkan gaya hidup penderita hipertensi di Puskesmas Bua Tallulolo Toraja Utara. Metode penelitian ini adalah deskriptif kuantitatif menggunakan teknik pengumpulan sampel yaitu purposive sampling dengan 286 responden. Hasil penelitian menunjukkan kepatuhan untuk selalu mencuci tangan sebanyak 228 orang (79.7\%), selalu menggunakan masker sebanyak 239 orang (83.6\%), selalu berjemur sebanyak 86 orang (30.1\%), selalu mengonsumsi sayur dan buah 158 orang (55.2\%), jarang mengonsumsi suplemen sebanyak 100 orang (35.0\%), rendah paparan asap rokok sebanyak 215 orang (75.2\%), cukup aktivitas sebanyak 142 orang (49.7\%), kebiasaan makan dan minum yang baik sebanyak 114 orang (39.9\%), dan tidak mengalami stress sebanyak 94 orang (32.9\%). Gaya Hidup sehat lebih sering dilakukan oleh responden perempuan dan responden pada kelompok usia 36-65 tahun. Pada umumnya penderita hipertensi di Puskesmas Bua Tallulolo memiliki gaya hidup yang sehat dan mematuhi protocol kesehatan. Penelitian dimasa depan diharapkan dapat menggali faktor-faktor yang mempengaruhi gaya hidup penderita hipertensi.
\end{abstract}

Kata kunci: COVID-19, gaya hidup, hipertensi.

\begin{abstract}
Covid-19 prevention efforts are related to changes in the lifestyle of people who are healthy and who suffer from comorbidities. Hypertension is known to be a susceptible comorbid and is associated with the severity of symptoms experienced by people with Covid-19. This study aims to describe the lifestyle of people with hypertension at the Bua Tallulolo Toraja Utara Health Center. This research method is descriptive quantitative utilizing purposive sampling technique with 286 respondents. The results showed that there were 228 people $(79.7 \%)$ adherence to always washing their hands, 239 people $(83.6 \%)$ always used masks, 86 people (30.1\%) always sunbathing, always eating 158 people $(55.2 \%)$ of vegetables and fruit, rarely consuming supplements as many as 100 people (35.0\%), low exposure to cigarette smoke as many as 215 people $(75.2 \%)$, sufficient activity as many as 142 people $(49.7 \%)$, good eating and drinking habits as many as 114 people (39.9\%), and not experiencing stress as many as 94 people (32.9\%). A healthy lifestyle is more often practiced by female respondents and respondents in the 36-65 year age group. In general, people with hypertension at the Bua Tallulolo Community Health Center have a healthy lifestyle and adhere to health protocols. Future research is expected to explore the factors that affect the lifestyle of people with hypertension.
\end{abstract}

Key words: COVID-19, lifestyle, hypertension. 


\section{PENDAHULUAN}

Gaya hidup sehat adalah salah satu resolusi yang perlu dihidupkan di era kenormalan baru. Gaya hidup sehat membutuhkan upaya-upaya menjaga dan mengatur keseimbangan gizi, keteraturan berolahraga atau beraktifitas, udara yang segar, dan cukup istirahat (COHIVE, 2021). Gaya hidup tidak sehat membawa dampak yang buruk pada kesehatan seseorang. Di Indonesia, gaya hidup yang tidak sehat menyebabkan angka kematian yang cukup tinggi. Kebiasaan hidup yang buruk berhubungan dengan merokok, tinggi asupan garam, kegemukan, kurang olahraga, dan yang tercemar(WHO, 2018).

Perilaku gaya hidup individu dan status kesehatan mempengaruhi resiko terinfeksi covid-19 (Gao et al., 2020). Hipertensi sebagai salah satu komorbid covid 19 yang paling umum, sangat erat hubungannya dengan gaya hidup. Perilaku yang tidak sehat menyebabkan hipertensi tidak terkontrol (Cherfan et al., 2020; Clark et al., 2021).

Dalam penelitian Hairunisa \& Amalia, 2020 dan Susilo et al., 2020, orang dengan komorbid menjadi salah satu kelompok yang paling rentan terpapar virus COVID-19. Penderita penyakit bawaan atau komorbid ini diketahui mendasari percepatan dan keparahan gejala covid, bahkan seringkali menyebabkan kematian (Sanyaolu et al., 2020). Penelitian membuktikan bahwa dari sejumlah pasien penderita covid yang meninggal sejumlah besar berhubungan dengan faktor komorbid (Satria et al., 2020).

Di Sulawesi Selatan jumlah kematian akibat COVID-19, 97\% dihubungkan dengan penyakit penyerta. Selanjutnya disebutkan bahwa komorbid memperparah kondisi pasien (PPNI, 2020b). Angka kematian pasien COVID19 yang berhubungan dengan komorbid menjadi suatu hal yang perlu mendapatkan perhatian serius dan khusus. Salah satu penyakit komorbid yang dapat berpotensi mengalami perburukan apabila terpapar COVID-19 adalah hipertensi (Larasati, 2021).

Di Indonesia, penderita hipertensi diperkirakan sebesar 15 juta dan hanya $4 \%$ yang merupakan hipertensi terkendali. Berdasarakan hasil Riskesdas (2014), prevalensi penderita hipertensi di Sulawesi Selatan mencapai 28,1\% dari 23 kabupaten/kota (Musfirah \& Hartati, 2021). Berdasarkan laporan yang disampaikan oleh Amanda (2020) dalam Kompas pada 18 Mei, terdapat $35 \%$ pasien COVID-19 yang merupakan pasien pengidap hipertensi, diabetes mellitus, dan penyakit kardiovaskuler lainnya. Sehingga orang dengan hipertensi memiliki resiko yang lebih tinggi untuk terifeksi COVID19. Hal ini dikarenakan penderita hipertensi memiliki imunitas lebih rendah, yang dapat memudahkan COVID-19 menginfeksi. Sebuah studi mengungkapkan orang dengan hipertensi mengalami gejala yang lebih berat ketika terinfeksi karena dapat menyebabkan komplikasi pada jantung, stroke dan gagal ginjal (Latifin, Purwanto, \& Wahyuni, 2020).

Pemerintah di Indonesia saat ini telah memberlakukan peraturan mengenai protocol kesehatan dengan 3M antara lain (1) Menggunakan masker saat beraktivitas, (2) Mencuci tangan dengan sabun, (3) Menjaga jarak minimal $1 \mathrm{~m}$. Selain itu, pemerintah juga menerapkan PSBB (Pembatasan Sosial Berskala Besar) semata mata dengan tujuan untuk memutus rantai COVID-19 yang saat ini semakin meningkat (Zendrato, 2020).

Puskesmas Bua Tallulolo Toraja Utara yang merupakan puskesmas utama yang berada di Kecamatan Kesu', telah memberlakukan protocol kesehatan seperti peraturan yang telah ditetapkan. Puskesmas Bua Tallulolo Toraja Utara tidak memperbolehkan masyarakat untuk mengunjungi puskesmas apabila tidak mematuhi protocol kesehatan 3M tersebut. Lanjut usia dengan hipertensi dan diabetes yang selama ini rutin melakukan posyandu setiap bulan, harus dihentikan untuk meningkatkan status kesehatan lansia, khususnya dengan tujuan menghentikan penyebaran virus COVID-19.

Pemerintah terus mengupayakan untuk mendorong masyarakat melakukan gaya hidup yang lebih sehat melalui kampanye GERMAS (Gerakan Masyarakat Hidup Sehat) dalam Instruksi Presiden Nomor 1 Tahun 2017 (Cahyani et al., 2020). Melakukan aktivitas fisik, makan buah dan sayur, tidak merokok, tidak 
mengkonsumsi minuman beralkohol, melakukan cek kesehatan berkala menjaga kebersihan lingkungan dan menggunakan jamban merupakan langkah yang dianjurkan GERMAS. Selain itu, pemerintah juga menciptakan program gaya hidup sehat seperti PHBS (Perilaku Hidup Bersih dan Sehat), Posbindu PTM, dan CERDIK (cek kesehatan secara rutin, enyahkan asap rokok, rajin aktivitas fisik, diet, istirahat cukup dan kelola stress). Program ini diciptakan oleh pemerintah untuk penanggulangan hipertensi di Indonesia, tetapi tidak menutup kemungkinan program tersebut dapat diterapkan untuk masyarakat umum (Susanti et al., 2021). Program tersebut dapat menjadi pedoman untuk mengimplementasikan hidup sehat di masa pandemik saat ini dengan mengambil beberapa kebiasaan yang sederhana .

Peningkatan tekanan darah disebabkan oleh banyak hal, termasuk gaya hidup (Fadhli, 2018). Meningkatkan kesadaran masyarakat serta mengarahkan pada perubahan pola hidup yang lebih sehat menjadi hal yang penting untuk menekan kasus hipertensi (Ngurah \& Yahya, 2014). Peningkatan resiko hipertensi dipengaruhi oleh gaya hidup yang tidak sehat, seperti kurang berolahraga, merokok, mengkonsumsi alcohol dan kopi, konsumsi makanan yang berlemak dan asin, serta mengalami stress (Evelin Malinti et al., 2020). Untuk itu, penguatan imunitas kelompok hipertensi sangat diperlukan dengan memperhatikan perilaku gaya hidup sehari-hari, terutama di masa pandemi COVID-19 saat ini. Beberapa penelitian telah mengupas mengenai gaya hidup selama masa pandemik, tetapi penelitian yang menitikberatkan pada gaya hidup penderita hipertensi selama masa pandemik masih terbatas. Berdasarkan latar belakang masalah tersebut, peneliti tertarik untuk mendapatkan "Gambaran Gaya Hidup Penderita Hipertensi di Puskesmas Bua Tallulolo Toraja Utara pada Masa Pandemi”.

\section{METODE PENELITIAN}

Penelitian ini menggunakan metode deskriptif kuantitatif yang bertujuan untuk menggambarkan bagaimana gaya hidup penderita hipertensi di wilayah kerja Puskesmas
Bua Tallulolo Pada Masa Pandemi. Jumlah responden dalam penelitian ini sebanyak 286 orang. Pemilihan sampel dilakukan menggunakan teknik purposive sampling, dimana responden adalah penderita hipertensi yang berada di Kecamatan Kesu' dengan kriteria, usia di atas 20 tahun dan bersedia untuk mengisi kuesioner dengan informed consent. Calon responden yang tuna aksara dan memiliki gangguan psikologis di eklusikan dari penelitian.

Data dikumpulkan menggunakan kuesioner yang diadopsi dari RAHMA, 2017 dan telah dilakukan uji validitas dengan nilai $>0,349$ dan untuk nilai reabilitasnya 0,737. Kuesioner terdiri dari isian data demografi dan 8 pertanyaan terkait gaya hidup. Pertanyaan tentang gaya hidup mencakup kebiasaan mencuci tangan, memakai masker pada saat keluar rumah, dan berjemur yang dijawab dengan pilihan selalu, kadang-kadang, jarang, dan tidak pernah. Kebiasaan merokok dan kebiasaan makan dan minum selama pandemik dijawab dengan ya atau tidak. Kemudian pertanyaan mengenai aktivitas fisik selama pandemik dijawab dengan memilih salah satu jawaban a atau b. Untuk variable stress selama pandemik menggunakan skala HARS (Hamilton Anxiety Rating Scale) dijawab dengan ya atau tidak (Artiyaningrum \& Azam, 2016).

Pengolahan data dilakukan dengan mencari distribusi frekuensi berdasarkan data demografi dan pertanyaan yang berhubungan dengan gaya hidup selama masa pandemi. Data diinput di Microsoft excel kemudian dicari frekuensi dan persentasenya.

\section{HASIL}

Total 286 responden yang ikut serta dalam penelitian ini dijabarkan berdasarkan distribusi karakteristik (table 1). Berdasarkan jenis kelamin laki-laki sebanyak 133 orang (46.5\%), dan perempuan 153 orang (53.6\%). Karakteristik responden berdasarkan usia dengan distribusi 20-35 tahun sebanyak 61 orang (21.3\%), 36-35 tahun sebanyak 166 orang $(58.0 \%)$, dan usia $>66$ tahun sebanyak 59 orang $(20.6 \%)$. 
Tabel 1. Distribusi karakteristik responden dan gaya hidup penderita hipertensi pada masa pandemi

\begin{tabular}{|c|c|c|}
\hline \multirow{2}{*}{ Variabel } & \multicolumn{2}{|c|}{ Jumlah } \\
\hline & $\mathbf{n}$ & $\%$ \\
\hline \multicolumn{3}{|l|}{ Jenis Kelamin } \\
\hline Laki-laki & 133 & 46.5 \\
\hline Perempuan & 153 & 53.6 \\
\hline \multicolumn{3}{|l|}{ Usia } \\
\hline $20-35$ & 61 & 21.3 \\
\hline $36-65$ & 166 & 58.0 \\
\hline$>66$ & 59 & 20.6 \\
\hline \multicolumn{3}{|l|}{ Kebiasaan Mencuci Tangan } \\
\hline Jarang & 3 & 1.0 \\
\hline Kadang-kadang & 55 & 19.2 \\
\hline Selalu & 228 & 79.7 \\
\hline \multicolumn{3}{|c|}{ Kebiasaan Menggunakan Masker } \\
\hline Jarang & 2 & 0.7 \\
\hline Kadang-kadang & 45 & 15.7 \\
\hline Selalu & 239 & 83.6 \\
\hline \multicolumn{3}{|l|}{ Kebiasaan Berjemur } \\
\hline Tidak pernah & 5 & 1.7 \\
\hline Jarang & 36 & 12.6 \\
\hline Kadang-kadang & 159 & 55.6 \\
\hline Selalu & 86 & 30.1 \\
\hline \multicolumn{3}{|c|}{ Kebiasaan Mengonsumsi Sayur dan Buah } \\
\hline Tidak pernah & 1 & 0.3 \\
\hline Jarang & 16 & 5.6 \\
\hline Kadang-kadang & 111 & 38.8 \\
\hline Selalu & 158 & 55.2 \\
\hline \multicolumn{3}{|c|}{ Kebiasaan Mengonsumsi Supplement } \\
\hline Tidak pernah & 21 & 7.3 \\
\hline Jarang & 100 & 35.0 \\
\hline Kadang-kadang & 98 & 34.3 \\
\hline Selalu & 67 & 23.4 \\
\hline \multicolumn{3}{|l|}{ Kebiasaan Merokok } \\
\hline Rendah paparan asap rokok & 215 & 75.2 \\
\hline Tinggi paparan asap rokok & 71 & 24.8 \\
\hline \multicolumn{3}{|l|}{ Tingkat Aktivitas } \\
\hline Kurang aktivitas & 144 & 50.3 \\
\hline Cukup aktivitas & 142 & 49.7 \\
\hline \multicolumn{3}{|c|}{ Kebiasaan Makan dan Minum } \\
\hline Baik & 114 & 39.9 \\
\hline Tidak baik & 172 & 60.1 \\
\hline \multicolumn{3}{|l|}{ Tingkat Kecemasan (Stress) } \\
\hline Tidak ada stress & 94 & 32.9 \\
\hline Stress ringan & 97 & 33.9 \\
\hline Stress sedang & 41 & 14.3 \\
\hline Stress berat & 49 & 17.1 \\
\hline Stress berat sekali & 5 & 1.7 \\
\hline Total & 286 & 100.0 \\
\hline
\end{tabular}

Distribusi berdasarkan gaya hidup selama pandemik, kebiasaan mencuci tangan lebih didominasi oleh responden yang selalu mencuci tangan dengan jumlah 228 orang (79.7\%). Kadang-kadang mencuci tangan sebanyak 55 orang (19.2\%), dan jarang mencuci tangan sebanyak 3 orang (1.0\%). Dalam hal menggunakan masker pada saat keluar rumah, responden yang selalu menggunakan masker sebanyak 239 orang $(83.6 \%)$. Responden yang kadang-kadang menggunakan masker sebanyak 45 orang (15.7\%), dan jarang menggunakan masker sebanyak 2 orang $(0.7 \%)$. Namun pada karakterisktik responden dalam hal berjemur didominasi oleh kebiasaan berjemur kadangkadang 159 orang (55.6\%), selalu berjemur sebanyak 86 orang $(30.1 \%)$, jarang berjemur 36 orang $(12.6 \%)$, dan tidak pernah berjemur sebanyak 5 orang $(1.7 \%)$.

Responden yang memiliki kebiasaan mengonsumsi sayur dan buah 158 orang $(55.2 \%)$ selalu mengkonsumsi, 111 orang $(38.8 \%)$ tergolong kadang-kadang mengkonsumsi. Sebanyak 16 orang $(5.6 \%)$ jarang mengkonsumsi sayur dan buah dan yang tidak pernah mengkonsumsi sebanyak 1 orang $(0.3 \%)$. Berdasarkan kebiasaan mengkonsumsi suplemen terdapat 100 orang $(35.0 \%)$ yang jarang mengkonsumsi, diikuti oleh yang tergolong kadang-kadang mengkonsumsi 98 orang (34.3\%). Responden yang selalu mengkonsumsi supplemen sebanyak 67 orang $(23.4 \%)$ dan tidak pernah mengonsumsi supplemen sebanyak 21 orang $(7.3 \%)$.

Responden yang rendah paparan asap rokok 215 orang $(75.2 \%)$ dan tinggi paparan asap rokok 71 orang $(24.8 \%)$. Dari segi tingkat aktivitas sebanyak 144 orang $(50.3 \%)$ yang kurang aktivitas. Responden yang cukup aktivitas sebanyak 142 orang (49.7\%). Dilain pihak, sebanyak sebanyak 172 orang (60.1\%) memiliki kebiasaan makan dan minum yang tidak baik, dan kebiasan yang baik sebanyak 114 orang (39.9\%). Responden yang mengalami stress ringan sebanyak 97 orang (33.9\%), tidak mengalami stress sebanyak 94 orang (32.9\%), mengalami stress berat sebanyak 49 orang $(17.1 \%)$, stress sedang sebanyak 41 orang $(14.3 \%)$ dan yang mengalami stress berat sekali sebanyak 5 orang $(1.7 \%)$. 
Table 2. Gaya Hidup Penderita Hipertensi selama Masa Pandemi berdasarkan Jenis Kelamin dan Usia

\begin{tabular}{|c|c|c|c|c|c|c|c|c|c|c|}
\hline \multirow{3}{*}{ Variabel } & \multicolumn{4}{|c|}{ Jenis Kelamin } & \multicolumn{6}{|c|}{ Usia (Tahun) } \\
\hline & \multicolumn{2}{|c|}{ Laki-laki } & \multicolumn{2}{|c|}{ Perempuan } & \multicolumn{2}{|c|}{ 20-35 } & \multicolumn{2}{|c|}{$36-65$} & \multicolumn{2}{|c|}{$>66$} \\
\hline & $\mathbf{n}$ & $\%$ & $\bar{n}$ & $\%$ & $\mathbf{N}$ & $\%$ & $\bar{n}$ & $\%$ & $\mathbf{n}$ & $\%$ \\
\hline \multicolumn{11}{|l|}{ Kebiasaan Mencuci Tangan } \\
\hline Jarang & 3 & 1.1 & 0 & 0 & 1 & 0.4 & 2 & 0.7 & 0 & 0 \\
\hline Kadang-kadang & 35 & 12.2 & 20 & 7.0 & 5 & 1.8 & 31 & 10.8 & 19 & 6.6 \\
\hline Selalu & 95 & 33.2 & 133 & 46.5 & 55 & 19.2 & 133 & 46.5 & 40 & 14.0 \\
\hline \multicolumn{11}{|c|}{ Kebiasaan Menggunakan Masker } \\
\hline Jarang & 2 & 0.7 & 0 & 0 & 0 & 0 & 2 & 0.7 & 0 & 0 \\
\hline Kadang-kadang & 29 & 10.1 & 16 & 5.6 & 13 & 4.6 & 26 & 9.1 & 6 & 2.1 \\
\hline Selalu & 102 & 35.7 & 137 & 47.9 & 48 & 16.8 & 138 & 48.2 & 53 & 18.5 \\
\hline \multicolumn{11}{|l|}{ Kebiasaan Berjemur } \\
\hline Tidak pernah & 4 & 1.4 & 1 & 0.4 & 0 & 0 & 5 & 1.8 & 0 & 0 \\
\hline Jarang & 23 & 8.0 & 13 & 4.6 & 12 & 4.2 & 16 & 5.6 & 8 & 2.8 \\
\hline Kadang-kadang & 75 & 26.2 & 84 & 29.4 & 34 & 11.9 & 91 & 31.8 & 34 & 11.9 \\
\hline Selalu & 31 & 10.8 & 55 & 19.2 & 15 & 5.2 & 54 & 18.9 & 17 & 5.9 \\
\hline \multicolumn{11}{|c|}{ Kebiasaan mengonsumsi Sayur dan Buah } \\
\hline Tidak pernah & 1 & 0.3 & 0 & 0 & 0 & 0 & 1 & 0.4 & 0 & 0 \\
\hline Jarang & 7 & 2.4 & 9 & 3.2 & 2 & 0.7 & 12 & 4.2 & 2 & 0.7 \\
\hline Kadang-kadang & 57 & 19.9 & 54 & 18,9 & 21 & 7.3 & 66 & 23.1 & 24 & 8.4 \\
\hline Selalu & 68 & 23.8 & 90 & 31.5 & 38 & 13.3 & 87 & 30.4 & 33 & 11.5 \\
\hline \multicolumn{11}{|c|}{ Kebiasaan Konsumsi Suplemen } \\
\hline Tidak pernah & 13 & 4.5 & 8 & 2.8 & 6 & 2.1 & 12 & 4.2 & 3 & 1.1 \\
\hline Jarang & 56 & 19.6 & 44 & 15.4 & 26 & 9.1 & 58 & 20.3 & 16 & 5.6 \\
\hline Kadang-kadang & 39 & 13.6 & 59 & 20.6 & 19 & 6.6 & 56 & 19.6 & 23 & 8.0 \\
\hline Selalu & 25 & 8.7 & 42 & 14.7 & 10 & 3.5 & 40 & 14.0 & 17 & 5.9 \\
\hline \multicolumn{11}{|l|}{ Kebiasaan Merokok } \\
\hline Rendah paparan asap rokok & 70 & 24.5 & 145 & 50.7 & 46 & 16.1 & 118 & 41.3 & 51 & 17.8 \\
\hline Tinggi paparan asap rokok & 63 & 22.0 & 8 & 2.8 & 15 & 5.2 & 48 & 16.8 & 8 & 2.8 \\
\hline \multicolumn{11}{|l|}{ Tingkat Aktivitas } \\
\hline Kurang aktivitas & 76 & 26.6 & 68 & 23.8 & 29 & 10.2 & 83 & 29.0 & 32 & 11.2 \\
\hline Cukup aktivitas & 57 & 19.9 & 85 & 29.7 & 32 & 11.2 & 83 & 29.0 & 27 & 9.4 \\
\hline \multicolumn{11}{|c|}{ Kebiasaan Makan dan Minum } \\
\hline Baik & 42 & 14.7 & 72 & 25.2 & 22 & 7.7 & 52 & 18.2 & 40 & 14.0 \\
\hline Tidak baik & 91 & 31.8 & 81 & 28.3 & 39 & 13.6 & 114 & 39.9 & 19 & 6.6 \\
\hline \multicolumn{11}{|l|}{ Tingkat Kecemasan (Stress) } \\
\hline Tidak ada stress & 42 & 14.7 & 52 & 18.2 & 31 & 10.8 & 51 & 17.8 & 12 & 4.2 \\
\hline Stress ringan & 47 & 16.4 & 50 & 17.5 & 19 & 6.6 & 61 & 21.3 & 17 & 6.0 \\
\hline Stress & 24 & 8.4 & 17 & 5.9 & 5 & 1.8 & 29 & 10.2 & 7 & 2.4 \\
\hline Stress berat & 18 & 6.3 & 31 & 10.8 & 6 & 2.1 & 24 & 8.4 & 19 & 6.6 \\
\hline Stress berat sekali & 2 & 0.7 & 3 & 1.1 & 0 & 0 & 1 & 0.4 & 4 & 1.4 \\
\hline Total & 133 & & 153 & & 61 & & 166 & & 59 & \\
\hline \multicolumn{4}{|c|}{$\begin{array}{l}\text { Dari tabel 2, menunjukkan gaya hidup } \\
\text { erita hipertensi selama pandemik } \\
\text { asarkan jenis kelamin dengan jumlah } \\
\text { nden laki-laki sebanyak } 133 \text { orang dan } \\
\text { npuan sebanyak } 153 \text { orang. Pada laki-laki, } \\
\text { mencuci tangan sebanyak } 95 \text { orang } \\
\% \text {, kadang-kadang sebanyak } 35 \text { orang } \\
\% \text { ), dan jarang mencuci tangan sebanyak } 3 \\
\text { (1.1\%). Kebiasaan mencuci tangan pada } \\
\text { npuan, dimana kategori selalu sebanyak }\end{array}$} & \multicolumn{7}{|c|}{$\begin{array}{l}133 \%(46.5 \%) \text {, kadang-kadang sebanyak } 20 \\
\text { orang }(7.0 \%) \text {, dan tidak ada perempuan dengan } \\
\text { hipertensi }(0 \%) \text { yang jarang mencuci tangan } \\
\text { selama pandemik. } \\
\text { Laki-laki yang selalu menggunakan } \\
\text { masker sebanyak } 102 \text { orang }(35.7 \%) \text {, kadang- } \\
\text { kadang sebanyak } 29 \text { orang }(10.1 \%) \text {, dan jarang } \\
\text { menggunakan masker sebanyak } 2 \text { orang }(0.7 \%) \text {. } \\
\text { Pada perempuan yang selalu menggunakan } \\
\text { masker sebanyak } 137 \text { orang }(47.9 \%) \text {, kadang- }\end{array}$} \\
\hline
\end{tabular}


kadang sebanyak 16 orang (5.6\%), dan tidak ada perempuan dengan hipertensi $(0 \%)$ yang jarang menggunakan masker pada saat keluar rumah selama pandemik.

Kebiasaan berjemur, dimana pada lakilaki lebih didominasi oleh kategori kadangkadang berjemur sebanyak 75 orang $(26.2 \%)$, selalu berjemur sebanyak 31 orang $(10.8 \%)$, jarang sebanyak 23 orang $(8.0 \%)$, dan tidak pernah berjemur sebanyak 4 orang (1.4\%). Begitupun pada perempuan, lebih didominasi oleh kategori kadang-kadang berjemur sebanyak 84 orang (29.4\%), selalu sebanyak 55 orang (19.2\%), jarang sebanyak 13 orang (4.6\%), dan tidak pernah berjemur sebanyak 1 orang $(0.4 \%)$.

Selalu mengonsumsi sayur dan buah pada laki-laki sebanyak 68 orang (23.8\%), kadang-kadang sebanyak 57 orang (19.9\%), jarang sebanyak 7 orang (2.4\%), dan tidak pernah mengonsumsi buah dan sayur sebanyak 1 orang $(0.3 \%)$. Selalu mengonsumsi sayur dan buah pada perempuan sebanyak 90 orang (31.5\%), kadang-kadang sebanyak 54 orang (18.9\%), jarang sebanyak 9 orang (3.2\%), dan tidak ada perempuan dengan hipertensi $(0 \%)$ yang tidak pernah mengonsumsi sayur dan buah selama pandemik.

Kebiasaan konsumsi supplement pada laki-laki, dimana kategori jarang sebanyak 56 orang (19.6\%), kadang-kadang sebanyak 39 orang $(13.6 \%)$, selalu sebanyak 25 orang $(8.7 \%)$, dan tidak pernah mengonsumsi supplement sebanyak 13 orang (4.5\%). Pada perempuan, lebih didominasi oleh kategori kadang-kadang sebanyak 59 orang (20.6\%), jarang sebanyak 44 orang (15.4\%), selalu sebanyak 42 orang (14.7\%), dan tidak pernah mengonsumsi supplement selama pandemik sebanyak 8 orang $(2.8 \%)$.

Kebiasaan merokok pada laki-laki dimana rendah paparan asap rokok sebanyak 70 orang (24.5\%), dan tinggi paparan asap rokok sebanyak 63 orang (22.0\%). Pada perempuan yang rendah paparan asap rokok sebanyak 145 orang $(50.7 \%)$, dan tinggi paparan asap rokok sebanyak 8 orang $(2.8 \%)$.

Tingkat aktivitas selama pandemik pada laki-laki dimana kurang aktivitas sebanyak 76 orang (26.6\%), dan cukupn aktivitas sebanyak 57 orang (19.9\%). Kemudian pada perempuan yang cukup aktivitas sebanyak 85 orang
(29.7\%), dan kurang aktivitas sebanyak 68 orang $(23.8 \%)$.

Kebiasaan makan dan minum pada lakilaki dimana kategori tidak baik sebanyak 91 orang $(31.8 \%)$, dan kategori baik sebanyak 42 orang (14.7\%). Pada perempuan, kebiasaan makan dan minum tidak baik sebanyak 81 orang $(28.3 \%)$, dan kategori baik sebanyak 72 orang $(25.2 \%)$.

Tingkat kecemasan selama pandemik pada laki-laki dengan tingkat stress ringan sebanyak 47 orang $(16.4 \%)$, tidak mengalami stress sebanyak 42 orang (14.7\%), stress sedang sebanyak 24 orang $(8.4 \%)$, stress berat sebanyak 18 orang $(6.3 \%)$, dan yang mengalami stress berat sekali sebanyak 2 orang $(0.7 \%)$. Pada perempuan, lebih didominasi oleh kategori tidak mengalami stress sebanyak 52 orang (18.2\%), stress ringan sebanyak 50 orang $(17.5 \%)$, stress berat sebanyak 31 orang $(10.8 \%)$, stress sedang sebanyak 17 orang (5.9\%), dan yang mengalami stress berat sekali sebanyak 3 orang $(1.1 \%)$.

Pada tabel yang sama (tabel 2), menunjukkan gaya hidup penderita hipertensi selama pandemik berdasarkan usia, dimana terdapat usia 20-35 tahun sebanyak 61 orang, usia 36-65 tahun sebanyak 166 orang, dan usia $>66$ tahun sebanyak 59 orang. Selalu mencuci tangan dengan sabun selama masa pandemik pada usia 20-35 tahun sebanyak 55 orang (19.2\%), kadang-kadang sebanyak 5 orang (1.8\%), dan jarang sebanyak 1 orang $(0.4 \%)$. Pada usia 36-65 tahun, selalu mencuci tangan sebanyak 133 orang (46.5\%), kadang-kadang sebanyak 31 orang (10.8\%), dan jarang sebanyak 2 orang $(0.7 \%)$. Pada usia $>66$ tahun yang selalu mencuci tangan sebanyak 40 orang (14.0\%), kadang-kadang sebanyak 19 orang (6.6\%), dan tidak ada (0\%) usia >66 tahun yang jarang mencuci tangan di masa pandemik saat ini.

Kebiasaan menggunakan masker saat keluar rumah selama pandemik pada usia 20-35 tahun dengan kategori selalu sebanyak 48 orang (16.8\%), kadang-kadang sebanyak 13 orang (4.6\%), dan tidak ada (0\%) usia 20-35 tahun yang jarang menggunakan masker pada saat keluar rumah. Kemudian pada usia 36-65 tahun, dimana selalu menggunakan masker sebanyak 138 orang (48.2\%), kadang-kadang sebanyak 26 orang $(9.1 \%)$, dan jarang sebanyak 2 orang 
(0.7\%). Pada usia >66 tahun yang selalu menggunakan masker sebanyak 53 orang $(18.5 \%)$, kadang-kadang sebanyak 6 orang $(2.1 \%)$, dan tidak ada (0\%) yang tidak menggunakan masker pada saat keluar rumah selama masa pandemik.

Pada usia 20-35 tahun, kadang-kadang berjemur sebanyak 34 orang (11.9\%), selalu sebanyak 15 orang (5.2\%), jarang sebanyak 12 orang $(4.2 \%)$, dan tidak ada (0\%) usia 20-35 tahun yang tidak berjemur di pagi hari selama masa pandemik. Pada usia 36-65 tahun, kadangkadang berjemur sebanyak 91 orang $(31.8 \%)$, selalu sebanyak 54 orang $(18.9 \%)$, jarang sebanyak 16 orang (5.6\%), dan tidak pernah berjemur sebanyak 5 orang $(1.8 \%)$. Begitupun pada usia $>66$ tahun yang lebih didominasi oleh kategori kadang-kadang berjemur sebanyak 34 orang (11.9\%), selalu sebanyak 17 orang (5.9\%), jarang sebanyak 8 orang $(2.8 \%)$, dan tidak ada $(0 \%)$ usia yang tidak pernah berjemur selama masa pandemik.

Kebiasaan mengonsumsi sayur dan buah selama masa pandemik pada usia 20-35 tahun dengan kategori selalu sebanyak 38 orang $(13.3 \%)$, kadang-kadang sebanyak 21 orang (7.3\%), jarang sebanyak 2 orang $(0.7 \%)$, dan tidak ada (0\%) usia 20-35 tahun yang tidak mengonsumsi sayur dan buah selama masa pandemik. Pada usia 36-65 tahun, selalu mengonsumsi sayur dan buah sebanyak 87 orang (30.4\%), kadang-kadang sebanyak 66 orang (23.1\%), jarang sebanyak 12 orang $(4,2 \%)$, dan tidak pernah mengonsumsi sayur dan buah sebanyak 1 orang $(0.4 \%)$. Usia $>66$ tahun yang selalu mengonsumsi sayur dan buah sebanyak 33 orang (11.5\%), kadang-kadang sebanyak 24 orang $(8.4 \%)$, jarang sebanyak 2 orang $(0.7 \%)$, dan tidak ada $(0 \%)$ usia $>66$ tahun yang tidak mengonsumsi sayur dan buah selama masa pandemik.

Jarang mengonsumsi supplement pada usia 20-35 tahun sebanyak 26 orang (9.1\%), kadang-kadang sebanyak 19 orang (6.6\%), selalu sebanyak 10 orang $(3.5 \%)$, dan tidak pernah sebanyak 6 orang $(2.1 \%)$. Usia 36-65 tahun, jarang mengonsumsi supplement sebanyak 58 orang $(20.3 \%)$, kadang-kadang sebanyak 56 orang (19.6\%), selalu sebanyak 40 orang $(14.0 \%)$, dan tidak pernah mengonsumsi supplement selama masa pandemik sebanyak 12 orang $(4.2 \%)$. Kemudian, pada usia $>66$ tahun kadang-kadang mengonsumsi supplement sebanyak 23 orang $(8.0 \%)$, selalu sebanyak 17 orang $(5.9 \%)$, jarang sebanyak 16 orang (5.6\%), dan tidak pernah mengonsumsi supplement sebanyak 3 orang (1.1\%).

Kebiasaan merokok selama masa pandemik pada usia 20-35 tahun dimana rendah paparan asap rokok sebanyak 46 orang (16.1\%), dan tinggi paparan asap rokok sebanyak 15 orang (5.2\%). Pada usia 36-65 tahun rendah paparan asap rokok sebanyak 118 orang (41.3\%), dan tinggi paparan asap rokok sebanyak 48 orang $(16.8 \%)$. Kemudian pada usia >66 tahun, rendah paparan asap rokok sebanyak 51 orang (17.8\%), dan tinggi paparan asap rokok sebanyak 8 orang $(2.8 \%)$.

Tingkat aktivitas selama masa pandemik pada usia 20-35 tahun dengan cukup aktivitas sebanyak 32 orang (11.2\%), dan kurang aktivitas sebanyak 29 orang (10.2\%). Pada usia 36-65 tahun memiliki jumlah orang yang sama dalam cukup dan kurang aktivitas sebanyak 83 orang (29.0\%). Kemudian pada usia $>66$ tahun kurang aktivitas sebanyak 32 orang (11.2\%), dan cukup aktivitas sebanyak 27 orang $(9.4 \%)$.

Kebiasaan makan dan minum selama masa pandemik pada usia 20-35 tahun yang tidak baik sebanyak 39 orang (13.6\%), dan baik sebanyak 22 orang (7.7\%). Pada usia 36-65 tahun, kebiasaan makan dan minum tidak baik sebanyak 114 orang (39.9\%), dan baik sebanyak 52 orang (18.2\%). Usia >66 tahun memiliki kebiasaan makan dan minum yang baik sebanyak 40 orang (14.0\%), dan yang tidak baik sebanyak 19 orang $(6.6 \%)$.

Tingkat stress selama masa pandemik pada usia 20-35 tahun, dimana tidak mengalami stress sebanyak 31 orang $(10.8 \%)$, stress ringan sebanyak 19 orang $(6.6 \%)$, stress berat sekali sebanyak 6 orang $(2.1 \%)$, stress sedang sebanyak 5 orang $(1.8 \%)$, dan tidak ada $(0 \%)$ usia 20-35 tahun yang mengalami stress berat sekali. Pada usia 36-65 tahun mengalami stress ringan sebanyak 61 orang (21.3\%), tidak mengalami stress sebanyak 51 orang (17.8\%), mengalami stress sedang sebanyak 29 orang (10.2\%), stress berat sebanyak 24 orang (8.4\%), dan yang mengalami stress berat sekali sebanyak 1 orang (0.4\%). Kemudian usia $>66$ tahun dengan stress berat sebanyak 19 orang $(6.6 \%)$, 
stress ringan sebanyak 17 orang $(6.0 \%)$, tidak mengalami stress sebanyak 12 orang (4.2\%), stress sedang sebanyak 7 orang (2.4\%), dan yang mengalami stress berat sekali sebanyak 4 orang $(1.4 \%)$.

\section{PEMBAHASAN}

Gaya hidup merupakan pola hidup seseorang yang dicerminkan dalam kegiatan, minat maupun dalam opininya. Gaya hidup menggambarkan bagaimana seseorang berinteraksi dalam lingkungannya. Sehingga gaya hidup yang sehat menjadi pilihan dari gaya hidup yang dipilih setiap individu untuk dilakukan dalam kehidupan sehari hari (Atmadja et al., 2020).

Pada kondisi pandemi saat ini, sangat diperlukan kerjasama dengan masyarakat untuk menghidupkan gaya hidup sehat dengan memahami terlebih mematuhi protocol kesehatan yang ditetapkan oleh pemerintah dengan tujuan untuk mengurangi penyebaran COVID-19 yang semakin meningkat (PPNI, 2020a).

COVID-19 dengan komorbid sangat mempengaruhi kerentanan seseorang terhadap kematian. Dimana salah satu kondisi kesehatan yang dapat memperburuk COVID-19 adalah hipertensi atau tekanan darah tinggi. Hipertensi adalah suatu kondisi dimana tekanan darah seseorang mencapai nilai sistolik $\geq 130 \mathrm{mmHg}$ dan diastolic $\geq 80 \mathrm{mmHg}$ (Kurnia \& Malinti, 2020). Menurut Kjeldsen et al., (2014); dan Zhang (2015), modifikasi gaya hidup menjadi hal yang utama untuk mengontrol kondisi tekanan darah (Zulfitri et al., 2019).

Dari tabel di atas, terdapat 286 responden dengan jenis kelamin laki-laki sebanyak 133 orang (46.5\%), dan perempuan 153 orang $(53.6 \%)$ yang mengalami hipertensi. Hal ini menunjukkan bahwa penderita hipertensi di Puskesmas Bua Tallulolo Toraja Utara lebih didominasi oleh perempuan. Hal tersebut sesuai dengan penelitian Amarrizka \& Imania, 2019 yang mengatakan bahwa hipertensi lebih didominasi oleh orang dengan jenis kelamin perempuan dibandingkan laki-laki, dikarenakan pada perempuan terjadi menopause sehingga mengakibatkan penurunan produksi hormone estrogen. Namun pernyataan tersebut tidak sesuai dengan penelitian yang dilakukan oleh Aristoteles, 2018 yang mengatakan bahwa jenis kelamin laki-laki lebih banyak yang menderita hipertensi dibandingkan dengan jenis kelamin perempuan, dikarenakan wanita sebelum mengalami menopause dilindungi oleh hormone estrogen yang berperan untuk meningkatkan kadar High Density Lipoprotein (HDL) sehingga akan terhindar dari penyakit kardiovaskuler.

Mayoritas penderita hipertensi adalah usia 36-65 tahun yaitu sebanyak 166 orang (58.0\%), kemudian diikuti oleh usia 20-35 tahun sebanyak 61 orang $(21.3 \%)$ dan $>66$ tahun sebanyak 59 orang (20.6\%). Hal ini sesuai dengan penelitian yang dilakukan oleh (Sundari \& Bangsawan, 2015) yang mengemukakan bahwa kejadian hipertensi akan semakin meningkat seiring dengan bertambahnya usia, yang disebabkan oleh perubahan alamiah dalam tubuh yang dapat mempengaruhi jantung, pembuluh darah serta hormone. Hal tersebut didukung oleh Depkes RI yang mengatakan bahwa tingginya hipertensi dipengaruhi oleh semakin bertambahnya umur, dimana terjadi perubahan struktur pada pembuluh darah besar, mengakibatkan lumen menjadi sempit dan juga dinding pembuluh darah akan lebih kaku (Sartik et al., 2017).

Mencuci tangan dengan sabun merupakan salah satu upaya yang dapat dilakukan untuk mencegah penyebaran COVID19. Menurut UNICEF 2020, mengatakan bahwa mencuci tangan yang baik dan benar dapat dilakukan dengan menggunakan sabun serta di bawah air mengalir dalam durasi waktu 20-30 detik (Elya et al., 2020). Melihat dari tabel di atas menunjukkan bahwa sebagian besar masyarakat di Puskesmas Bua Tallulolo dengan riwayat hipertensi sudah patuh dalam mencuci tangan dengan sabun.

Menggunakan masker merupakan salah satu anjuran yang ketat dari pemerintah untuk diterapkan selama masa pandemik ini. Penggunaan masker merupakan langkah yang dapat dilakukan untuk memutus rantai penyebaran COVID-19. Menurut Shereen et al., 2020, COVID-19 yang dapat ditularkan melalui saluran pernapasan serta melalui kontak dengan benda terkontaminasi merupakan alasan untuk 
mewajibkan seluruh masyarakat terutama orang dengan komorbid untuk menggunakan masker ketika keluar dari rumah maupun berinteraksi dengan orang lain (Mushidah \& Ratna Muliawati, 2021). Data pada tabel 1 menunjukkan bahwa orang dengan hipertensi pada Puskesmas Bua Tallulolo telah menerapkan salah satu protokol kesehatan yaitu menggunakan masker pada saat keluar rumah.

Menurut Nimitphong and Holick, 2013; Lucas et al., 2018, Vitamin D yang didapat dari sinar matahari berfungsi untuk meningkatkan system kekebalam tubuh dan dapat menangkal beberapa penyakit khususnya COVID-19. Selain itu, vitamin $\mathrm{D}$ sangat diperlukan bagi orang dengan hipertensi untuk mengurangi tekanan darah tinggi, yang dapat diperoleh dengan berjemur diatas jam 09.00 pagi dan sebaiknya dilakukan 10-30 menir dalam sehari (Elya et al., 2020). Namun, berbeda halnya pada orang dengan hipertensi di Puskesmas Bua Tallulolo, yang lebih memilih kadang-kadang untuk berjemur selama masa pandemik saat ini.

Dalam kondisi pandemik saat ini, masyarakat perlu mempertimbangkan makanan yang bergizi. Juga sangat penting bagi orang dengan hipertensi untuk mengonsumsi sayur dan buah yang mengandung vitamin $\mathrm{C}$ dan $\mathrm{E}$ yang dapat meningkatkan kekebalan tubuh pada masa pandemic saat ini (Akbar \& Aidha, 2020). Orang dengan hipertensi di Puskesmas Bua Tallulolo lebih didominasi oleh kategori selalu mengonsumsi sayur dan buah pada masa pandemik sekarang ini.

Konsumsi supplement bagi orang dengan hipertensi sangat membantu untuk menurunkan tekanan darah tinggi, namun pada masa pandemik saat ini disarankan untuk mengurangi supplement dengan mengikuti cara alami untuk meningkatkan kekebalan tubuh seperti vitamin D dari sinar matahari dan memperhatikan pola makan yang seimbang (Millah, 2020). Di Puskesmas Bua Tallulolo dapat dikatakan bahwa orang dengan hipertensi membatasi untuk mengonsumsi supplement dengan melihat kategori jarang mengonsumsi supplement yang lebih mendominasi yaitu sebanyak 100 orang $(35.0 \%)$,
Seperti yang diketahui merokok dapat menyebabkan tekanan darah tinggi dikarenakan zat-zat kimia yang terdapat di dalam tembakau mampu merusak lapisan dinding dalam arteri sehingga terjadi penumpukan plak di arteri (Susanti, Anita, \& Santoso, 2021). Dalam data yang diperoleh, kebiasaan merokok pada orang dengan hipertensi menunjukkan bahwa sebagian masyarakat di Puskesmas Bua Tallulolo dimana orang dengan hipertensi tidak merokok dan rendah paparan asap rokok.

Menurut Paruntu et al., dalam studinya mengatakan bahwa aktivitas fisik mampu meningkatkan kekebalan tubuh, semakin sering seseorang melakukan aktivitas fisik maka semakin kecil peluang seseorang mengalami tekanan darah tinggi (Atmadja et al., 2020). Hal tersebut sesuai dengan Rêgo et al., 2019, yang mengatakan bahwa dengan latihan fisik mampu mengurangi resiko kerusakan fungsi kognitif, serta efisien dan efektif dalam penanganan tekanan darah tinggi (Eva Malinti \& Malinti, 2020). Namun, data yang diperoleh di Puskesmas Bua Tallulolo dimana orang dengan hipertensi lebih banyak yang kurang melakukan aktivitas, hal tersebut bisa dikarenakan aturan dari pemerintah yang menganjurkan untuk tetap berada di rumah (stay at home) selama pandemic dengan tujuan mengurangi penyebaran virus COVID-19, sehingga masyarakat tetap berada di rumah selama pandemi.

Pola hidup sehat pada orang dengan hipertensi perlu memperhatikan kebiasaan makan dan minum. Dapat dimulai dengan membatasi konsumsi garam, menghindari makanan berlemak tinggi, menghindari makanan dan minuman instan serta menghindari minuman yang mengandung alcohol dan kafein (Larasati, 2021). Data yang diperoleh dari orang dengan hipertensi di Puskesmas Bua Tallulolo lebih memiliki kebiasaan makan dan minum yang tidak baik. Dalam penelitian (Arifin et al., 2020), peningkatan tekanan darah dipengaruhi oleh diameter pembuluh darah arteri yang mengecil sehingga jantung memompa darah lebih kuat, hal ini bisa disebabkan oleh pola makan dan minum yang tidak baik.

Tingkat kecemasan pada orang dengan hipertensi, menunjukkan bahwa pada masa 
pandemik saat ini, khususnya pada orang dengan hipertensi mengalami kecemasan yang tinggi. Banyak hal yang dapat meningkatkan kecemasan terutama pada masa pandemic saat ini, sehingga kecemasan dapat menyebabkan menurunnya system kekebalan tubuh serta dapat meningkatkan tekanan darah (Sirait et al., 2020).

Gaya hidup penderita hipertensi selama masa pandemik berdarsakan jenis kelamin dengan melihat dari data pada tabel 2, menunjukkan bahwa gaya hidup penderita hipertensi dengan jenis kelamin perempuan lebih mendominasi dalam menerapkan gaya hidup yang sehat di masa pandemik saat ini dibandingkan dengan laki-laki. Namun tidak dapat di pungkiri bahwa masih terdapat beberapa orang dengan jenis kelamin perempuan yang masih tidak menerapkan gaya hidup yang sehat, dan begitupun dengan laki-laki terdapat beberapa yang sudah menerapkan gaya hidup yang sehat di masa pandemic saat ini. Data tersebut sesuai dengan penelitian yang dilakukan oleh (Simanjuntak et al., 2020) yang mengatakan bahwa perempuan lebih mematuhi dan menerapkan protocol kesehatan dibanding laki-laki pada masa pandemic saat ini.

Berdasarkan data yang didapatkan dari tabel 2 tersebut menunjukkan bahwa pada usia 36-65 tahun lebih mendominasi dalam melakukan gaya hidup yang sehat selama pandemic. Gaya hidup masyarakat tersebut yang lebih protektif dalam hal pola hidup yang sehat selama masa pandemic ini dapat dipengaruhi oleh informasi serta pengetahuan yang didapatkan. Menurut Suryanto dalam Wantiyah 2004 yang mengatakan bahwa usia yang lebih mudah menerima informasi yang bersifat dinamis adalah usia muda (Utama, 2020). Dalam hal tersebut tidak sesuai dengan data yang didapatkan bahwa usia 36-65 tahun lebih mematuhi gaya hidup sehat selama pandemic dibandingkan dengan usia 20-35 tahun.

\section{KESIMPULAN}

Berdasarkan hasil penelitian dapat disimpulkan bahwa selama masa pandemik saat ini, sebagian besar penderita hipertensi di Puskesmas Bua Tallulolo Toraja Utara memiliki gambaran gaya hidup sehat dan mematuhi protokol kesehatan dari pemerintah. Namun tidak dapat dipungkiri masih terdapat beberapa orang dengan hipertensi yang memiliki gaya hidup yang tidak sehat dan tidak mematuhi protokol kesehatan. Penelitian lebih lanjut hendaknya dilakukan dengan menggunakan beberapa pertanyaan yang mengacu pada gaya hidup sehat orang dengan hipertensi seperti kebiasaan pola istirahat dan kepatuhan terhadap social distancing pada masa pandemic saat ini.

\section{DAFTAR PUSTAKA}

Akbar, D. M., \& Aidha, Z. (2020). Perilaku Penerapan Gizi Seimbang Masyarakat Kota Binjai pada Masa Pandemi COVID19 tahun 2020. Jurnal Menara Medika, $3(1), 15-21$.

https://doi.org/https://doi.org/10.31869/mm .$v 3 i 1.2193$

Amarrizka, M., \& Imania, D. R. (2019). Hubungan Usia, Jenis Kelamin, Pekerjaan terhadap Kejadian Hipertensi di RSUD Panembahan Senopati Bantul. Universitas 'Aisyiyah Yogyakarta, 1-13.

Arifin, B., Zaenal, S., \& Irmayani. (2020). Hubungan Gaya Hidup dengan Kejadian Hipertensi di Puskesmas Sabutung Kabupaten Pangkep. Jurnal Ilmiah Kesehatan Diagnosis, 15(3), 227-231.

Aristoteles. (2018). Korelasi Umur dan Jenis Kelamin dengan Penyakit Hipertensi di Emergency Center Unit Rumah Sakit Islam Siti Khadijah Palembang 2017. Indonesia Jurnal Perawat, 3(1), 9-16.

Artiyaningrum, B., \& Azam, M. (2016). FaktorFaktor yang Berhubungan dengan Kejadian Hipertensi Tidak Terkendali pada Penderita yang Melakukan Pemeriksaan Rutin. Public Health Perspective Journal, 1(1), 12-20.

Atmadja, T. F. A., Yunianto, A. E., Yuliantini, E., Haya, M., Faridi, A., \& Suryana, S. (2020). Gambaran Sikap dan Gaya hidup Sehat Masyarakat Indonesia selama Pandemi COVID-19. AcTion: Aceh Nutrition Journal, 5(2), 195. https://doi.org/10.30867/action.v5i2.355 
Cahyani, D. I., Kartasurya, M. I., \& Rahfiludin, M. Z. (2020). Gerakan Masyarakat Hidup Sehat dalam Perspektif Implementasi Kebijakan (Studi Kualitatif). Jurnal Kesehatan Masyarakat Indonesia, 15(1), $10-18$. https://doi.org/10.26714/jkmi.15.1.2020.10 $-18$

Cherfan, M., Vallée, A., Kab, S., Salameh, P., Goldberg, M., Zins, M., \& Blacher, J. (2020). Unhealthy behaviors and risk of uncontrolled hypertension among treated individuals-The CONSTANCES population-based study. Scientific Reports, 10(1), 1-12. https://doi.org/10.1038/s41598-020-586851

Clark, C. E., McDonagh, S. T. J., McManus, R. J., \& Martin, U. (2021). COVID-19 and hypertension: risks and management. A scientific statement on behalf of the British and Irish Hypertension Society. Journal of Human Hypertension, 304-307. https://doi.org/10.1038/s41371-020-00451$\mathrm{x}$

\section{COHIVE. (2021). No TitleStarting a Healthy} Life in the New Normal Era. https://cohive.space/blogs/starting-ahealthy-life-in-the-new-normal-era/

Elya, Fajar, W. I., Eliza, Yunianto, A. E., Yuliantini, E., Haya, M., \& Faridi, A. (2020). Kebiasaan Cuci Tangan, Berjemur, dan Media Informasi pada Masyarakat Sumatra Selatan selama Masa Pandemi COVID-19. Jurnal Media Kesehatan, 13(2), 59-66.

https://doi.org/https://doi.org/10.33088/jmk .v13i2.519

Fadhli, W. M. (2018). Hubungan antara Gaya Hidup dengan Kejadian Hipertensi pada Usia Dewasa Muda di Desa Lamakan Kecamatan Karamat Kabupaten Buol. Jurnal KESMAS, 7(6), 1-14.

Gao, C., Zhao, Z., Li, F., Liu, J. L., Xu, H., Zeng, Y., Yang, L., Chen, J., Lu, X., Wang, C., \& Guo, Q. (2020). The impact of individual lifestyle and status on the acquisition of COVID-19: A case-Control study. PLoS ONE, 15(11 November), 1-9. https://doi.org/10.1371/journal.pone.02415 40

Kurnia, S. H. T., \& Malinti, E. (2020). Hubungan Kebiasaan Konsumsi Kopi dan Merokok dengan Tekanan Darah Laki-Laki Dewasa. Nutrix Journal, 4(1), 1-4. https://doi.org/https://doi.org/10.37771/nj. Vol4.Iss 1.420

Larasati, D. (2021). Peningkatan Informasi Penyakit dengan Komorbid Hipertensi pada Masa Pandemi COVID-19 di Puskesmas Piyungan. Jurnal Abdimas Madani, 3(1), 21-25.

Malinti, Eva, \& Malinti, E. (2020). Tekanan Darah dan Hubungannya dengan Indeks Massa Tubuh dan Aktifitas Fisik pada Wanita Dewasa. Jurnal Ilmiah Keperawatan, 6(2), 178-183. https://doi.org/https://doi.org/10.33023/jike p.v6i 2.578

Malinti, Evelin, Elon, Y., \& Wulandari, I. S. M. (2020). Factors Associated With Blood Pressure Of Adult Clients. Dunia Keperawatan: Jurnal Keperawatan Dan Kesehatan, 8(3), 425-434. https://doi.org/10.20527/dk.v8i3.8277

Millah, S. (2020). Berapa Banyak Suplemen Vitamin D yang Baik untuk Pasien Covid19? Bisnis.Com.

Musfirah, \& Hartati, A. N. (2021). Faktor yang berhubungan dengan Kejadian Hipertensi di Puskesmas Polong Bangkeng Utara Kecamatan Polong Bangkeng Utara Kabupaten Takalar. PREPOTIF Jurnal Kesehatan Masyarakat, 5(1), 56-67.

Mushidah, \& Ratna Muliawati. (2021). Pengetahuan dan Sikap dengan Kepatuhan Penggunaan Masker sebagai Upaya Pencegahan Penyebaran COVID-19 pada Pedagang UMKM. Jurnal Ilmiah Permas: Jurnal Ilmiah STIKES Kendal, 11(1), 3542. 
Ngurah, I. G. K. G., \& Yahya, N. K. V. C. (2014). Gaya Hidup Penderita Hipertensi. Jurnal Ilmu Kesehatan, 2(3), 1-6.

PPNI. (2020a). Ini Cara Menuju Tatanan Kehidupan Baru di Masa Pandemi COVID-19. Https://Ppni-Inna.Org/.

PPNI. (2020b). Komorbid Menjadi Penyebab Kematian Bagi Pasien Covid-19. Https://Ppni-Inna.Org/.

RAHMA, N. M. (2017). Gambaran Gaya Hidup Penderita Hipertensi pada Masyarakat Pesisir. In Skripsi (Issue April).

Sanyaolu, A., Okorie, C., Marinkovic, A., Patidar, R., Younis, K., Desai, P., Hosein, Z., Padda, I., Mangat, J., \& Altaf, M. (2020). Comorbidity and its Impact on Patients with COVID-19. SN Comprehensive Clinical Medicine, 2(8), 1069-1076. https://doi.org/10.1007/s42399-020-003634

Sartik, Tjekyan, R. S., \& Zulkarnain, M. (2017). Faktor-Faktor Risiko dan Angka Kejadian pada Penduduk Palembang. Jurnal Ilmu Kesehatan Masyarakat, 8(3), 180-191. https://doi.org/DOI: https://doi.org/10.26553/jikm.2017.8.3.180 $-191$

Satria, R. M. A., Tutupoho, R. V., \& Chalidyanto, D. (2020). Analisis Faktor Risiko Kematian dengan Penyakit Komorbid Covid-19. Jurnal Keperawatan Silampari, 4(1), 48-55. https://doi.org/https://doi.org/10.31539/jks. v4i1.1587

Simanjuntak, D. R., Napitupulu, T. M., Wele, A. M., \& Yanie, R. (2020). Gambaran Kepatuhan Masyarakat Menerapkan Protokol Kesehatan COVID-19 di Tempat Umum Periode September 2020 di DKI Jakarta. Fakultas Kedokteran Universitas Kristen Indonesia.
Sirait, H. S., Dani, A. H., \& Maryani, D. R. (2020). Hubungan Pengetahuan tentang COVID-19 terhadap Tingkat Kecemasan pada Lansia yang mengalami Hipertensi. Jurnal Kesehatan, 11(2), 165-169. https://doi.org/http://dx.doi.org/10.38165/j $\mathrm{k}$.

Sundari, L., \& Bangsawan, M. (2015). FaktorFaktor Yang Berhubungan Dengan Kejadian Hipertensi. Jurnal Keperawatan, 11(2), 216-223. https://doi.org/http://dx.doi.org/10.26630/j kep.v11i2.575

Susanti, Y., Anita, \& Santoso, D. Y. A. (2021). Perilaku Cerdik Penderita Hipertensi Dimasa Pandemi COVID-19. Jurnal Keperawatan, 13(1), 61-76. https://doi.org/https://doi.org/10.32583/kep erawatan.v13i1.1116

Utama, L. J. (2020). Gaya Hidup Mayarakat Nusa Tenggara Timur dalam Menghadapi Pandemi Corona Virus Disease 19 (COVID-19). Jurnal Kesehatan Masyarakat, 7(1), 34-40.

WHO. (2018). NCDs Country Profiles 2018 WHO. 224. https://www.who.int/nmh/publications/ncd -profiles-2018/en/

Zendrato, W. (2020). Gerakan Mencegah Daripada Mengobati Terhadap Pandemi Covid-19. Jurnal Education and Development, 8(2), 242-248.

Zulfitri, R., Indriati, G., Amir, Y., \& Nauli, F. A. (2019). Pemberdayaan Keluarga Sadar Hipertensi (GADARSI) dalam Peningkatan Gaya Hidup Sehat Penderita Hipertensi. Jurnal Ners Indonesia, 9(2), 182-188. https://doi.org/10.31258/jni.9.2.182-188 